\title{
The Extradition Measures under International Agreements in the Ineffectiveness of the Relevant Internal Law for the Enforcement of Detention of Suspects
}

\author{
Dolnapa Nantawaroprai \\ Faculty of Law, Krirk University \\ Annbluesky@gmail.com
}

\begin{abstract}
Extradition is an international process which states expect to achieve the goal an accused brought to justice in territory of a requesting state where such person has committed a crime. However, there are a number of factors affecting extradition and causing it to be ineffective, such as diplomacy, politics, and so on. Therefore, states should seriously cooperate in the extradition with sincerity.
\end{abstract}

Keywords

Extradition of Requested State, Exceptions of Extradition, Extradition Cases of Thailand.

Article Received: 10 August 2020, Revised: 25 October 2020, Accepted: 18 November 2020

\section{Introduction}

For decades, there have been offences committed in Thailand by the accused who then escaped from Thai Judicial Process to hide in a state which does not have extradition agreement with Thailand. Although the Extradition Act was legislated in B.E. 2551 (2008), effective enforcement has not existed. As a result, a suspect or does not fear law enforcement as they are confident that they shall not be brought to punishment under the law.

The abovementioned issue affects relevant agencies, the authorities of which are responsible for extradition. For example, the Office of the Attorney General and Thai Royal Police have been reviled that they are not capable of carrying out the extradition effectively.

\section{Definition of extradition}

Extradition refers to a process that a requesting state requests another state (hereinafter "requested state") to extradite an accused who committed a criminal offence under its law and currently resides in the requested state to the requesting state to stand trial there. The other purpose of extradition is to extradite a fugitive who had been sentenced in the requesting state but somehow managed to escape to the requested state back to serve a punishment in the requesting state 1

Principle of Extradition in accordance with international agreements and relevant domestic laws.

\subsection{Principle of Extradition in accordance with international agreement or treaty}

According to the extradition under the obligation prescribed in a treaty, regardless of Thailand is a requesting state or a requested state, Thai officials shall firstly consider if there is an extradition treaty between Thailand and the requested or requesting state or not. If there is such a treaty, Thai officials shall perform duty in accordance with the obligations under the treaty. If there is no such treaty, the Thai officials shall perform duty under the condition of reciprocity as provided in Section 4 of the Extradition Act, B.E. 2551 (2008) which states that "This Act shall be enforce upon the extradition that is not conflicting with or contradictory to the provisions under the treaty respecting extradition between the Government of Thailand and the Government of a Foreign Country or international organization.

According to the provision provided in Section 4 mentioned above, it can lay down a guideline in the case that there is/are provision(s) under the extradition treaty which is/are not consistent with the Extradition Act. Extradition shall be carried out in accordance with the treaty, not domestic law where there is a conflict between the domestic law and the treaty.

\subsection{Extradition under the principle of reciprocity}

Reciprocity refers to a condition that when a requested state extradite a person sought to a requesting state. In the future, if the requested state which extradites the person sought to the requesting state needs to ask the country in which the person sought resides to extradite such person to it, the requested state (previously the requesting state) shall execute the extradition request in return.

However, the execution of an extradition request under the principle of reciprocity could come across obstacles. For example, when Thailand is requested to extradite a fugitive but an offence he/she committed in the requesting state carries death penalty under the Thai law, some requesting states may not be able to undertake reciprocity since they do not have death penalty. Likewise, they shall not extradite a fugitive to face justice in Thailand for fear that such fugitive may be punished by death penalty in Thailand2 Despite this, extradition from the state that does not have death penalty to Thailand can be executed if Thailand assures a requested state that it shall not give punishment by death to the fugitive extradited from that 
state as provided in Article 29 Extradition Act, B.E. 2551 (2008).

\subsection{Extradition considered on the basis of double criminality}

Under the principle of double criminality, an extraditable offence must be a criminal one that is established by laws of both requesting and requested states. For example, if Thailand submits its extradition request to Switzerland to extradite a person committing tax offence, the request does not comply with the condition of Switzerland since tax offence is not a criminal offence, but it is a civil offence in Switzerland. However, the principle of double criminality could be exempted if there is an extradition treaty which provides an exception as such between a requesting and requested states.

\subsection{Extradition considered based on an offence having punishment from one year upward}

An offence to be extraditable must be a criminal one that both the law of a requesting and a requested state establish it to be a criminal offence having punishment by death or imprisonment or deprivation of liberty from one year upward,. However, such offence needs not to have the same scale of punishment or the same name under the laws of both states.

The reason why the scale of the punishment is one year upward is that there are processes related to many authorities for an execution of the extradition. As a result, this process usually takes a long period of time. Thus, it is not worth to extradite a person committing a petty offence or an offence with low scale of punishment.

However, in case there is an extradition treaty which was specially agreed by both parties to comply with obligations to extradite a person who escape imprisonment. For example, as Article 2(1) paragraph 2 of the Treaty between the Government of the United State of America and the Government of the Kingdom of Thailand Relating to Extradition A.D. 1991 provides below3: (Treaty between the Government of the United State of America and the Government of the Kingdom of Thailand Relating to Extradition B.E. 2353 (1991)).

"For the enforcement of a penalty or detention order for such an extraditable offence, extradition shall be granted if the duration of the penalty or detention order still to be served amounts to at least six months."

From the above provision, the extradition shall be executed although the remaining period of punishment is less than one year. It is also important to note that the punishment of a person who escapes imprisonment or confinement must be an extraditable one.

\section{Exception of extradition refusal}

3.1 Political offence has often been claimed to refuse the execution of extradition request since the ancient time, and it has become international custom. Consequently, this study aims to investigate the meaning of political offence claim, political offence consideration, and prohibition of political offence claim which are described as follows.
(1) In case that extradition of a person committing a political offence is requested, a requested state may not execute such request. In order to consider if any offence is a political one or not, status of the person committing an offence is usually taken into account. If a person sought for extradition holds or held any political position and committed an offence for the political purpose, the offence he committed is considered as a political one, his offence tends to be considered as a political one. This is because it is the intention of international community not to punish a politician with the criminal offence he committed, such as, cheating in an election, Coup d'etat, etc., although $\mathrm{h}$ it is a serious offence. And as it is controversial to decide if an offence is a political offence or not, the government of a requested state shall solely have authority to decide on a basis of political reason.

Take the case of Treaty between the Kingdom of Thailand and the Kingdom of Cambodia on Extradition A.D. 1998 as an example.

Article 3(1) of the Treaty states that Extradition shall not be granted under this treaty if the Requested Party considers the offence for which the request for extradition is made by the Requesting Party as a political offence. This reflects that the Requested Party shall solely have right to consider such offence. The Treaty does not provide that a Requested and a Requesting Party shall jointly a political offence. As a result, a number of accused committing an offence in Thailand chose to escape to Cambodia. For example, Mr. Wattana Atsawahem, a defendant in Klong Dan case who escaped from Thailand, was sentenced to 10 years in prison with an offence of wrongful exercise of his function as Deputy Minister of Interior by the Criminal Case Division for Persons Holding Political Position of the Supreme Court of Thailand. He induced official of Samut Prakarn Provincial Land Office to issue a title deed of 1,900 rai of land located in Klong Dan district in Samut Prakarn province to Palm Beach Development Company.

During the Supreme Court consideration of this case, he escaped and did not appear at the court for hearing the judgement. The Supreme Court thus issued an arrest warrant to seize him to be punished by imprisonment for 10 years. The period of prescription of this case is 15 years. Although there was a clue that he escaped to People's Republic of China and then, the Kingdom of Cambodia4 (Naew Na online, B.E. 2563) the Thai government somehow has never requested his extradition from Cambodia.

\subsection{Military offence claim}

There is a provision provided in Section 9(1) Extradition Act, B.E. 2551 (2008) which is in line with most extradition treaties which do not include an military offence as an extraditable one. However, where a soldier commits a criminal offence which is also a military offence, that soldier could be extradited.

\subsection{Case terminated by prescription}

Extradition shall not be applied to a case terminated by prescription. This is in line with a general provision of law in every state that legal proceedings shall not be taken if the case is terminated by prescription. Despite such principle, 
some international treaties provide that a case shall not be extraditable unless it is still in a period of prescription under the laws of both a requested and a requesting states. Against this background, some treaties provide that whether a case shall be extraditable or not depends on a period of prescription of a requesting state. It means that although a case is terminated by prescription according to law of a requested state, such case can be extraditable. This condition is reflected in Section 10 Extradition Act, B.E. 2551 (2008) stating that "Where any persons sought for extradition...state for limitation is lapsed or there arises any other causes barring the proceedings against such person under the law of the Requesting State such person shall not be re extradited in respect of such conduct" According to Thai law, it can be interpreted that a case to be extraditable must be in a period of prescription based on law of a requesting state, and a period of prescription based on law of a requested state shall not be applied, unless there is a treaty between both states provides otherwise.

\subsection{Case of a sought person who was acquitted or already served punishment}

A person who had already been prosecuted in a court of either a requesting or a requested state and was later acquitted by court decision or completely served his punishment shall not be re extradited. This is in line with the principle of Double Jeopardy . Furthermore, Rome Statue of International Criminal Court A.D. 1998 provides a crucial condition in Article 20 that a person shall not be twice tried for the same offence in order to set the final condition of legal proceedings which International Criminal Court is prohibited from rendering punishment to a person who has been already convicted or acquitted (No person shall be twice tried) 5 as follows.

1. A person who was convicted or acquitted by court decision according to crime he committed shall not be tried.

2.No person shall be tried by another court for a crime referred to in article 5 for which that person has already been convicted or acquitted by the Court.

3 No person who has been tried by another court for conduct also proscribed under article $6,7,8$ shall be tried by the Court with respect to the same conduct unless the proceeding in the court were not conducted independently or impartially in accordance with the norms of due process recognized by international law and were conducted in a manner which, in the circumstances, was inconsistent with an intent to bring the person concerned to justice.

\subsection{Prohibition of prosecution and punishment for an offence committed prior to executing extradition}

After an extradition is executed, a requesting state shall not prosecute a person sought for an offence committed before surrendering process and not prescribed in the extradition request. In other words, a requesting state shall prosecute and punish an extradited person for only an offence specified in the extradition request (Rule of Specialty). If a requesting state would like to prosecute an extradited person for an offence committed prior to surrendering process, it shall initially seek consent from a requested state except in the case that such person has traveled out of the territory of a requesting state after completion of the extradition process and voluntarily returned to it, or not traveled out of the territory of a requesting state within a period prescribed by law, such as, 30 days after he is granted freedom to travel from such state as prescribed in Section 11 Extradition Act, B.E. 2551 (2008)

\subsection{Extradition of a national}

In the past, a state did not extradite its own national. Accordingly, extradition treaties nowadays gives right to contracting parties to refuse to execute extradition request of their nationals Nevertheless, many extradition treaties provide exceptions of such principle. This reflects that it depends on decision of a requested state to refuse or execute a request.

The to refuse extradition of a national sometimes is blocked by political pressure. For example, a Thai citizen who had been accused of committing narcotic offence was extradited to the United States of America. In this case, if Thailand refused, it would have been considered not to support narcotic suppression and would have been blamed and sanctioned by any means.

The above example refers to the case of Mr. Tanong Siripongpreecha who was sought for extradition for narcotic offence by the United States of America. In B.E. 2537 (1994), he was alleged for being involved with narcotic trafficking for 17 years by the Drug Enforcement Administration: (DEA) of the United States of America6 However, Mr. Tanong, who was a politician at the time, refused such allegation and told that he was framed. Then, he decided to quit Chat Thai party to defend the allegation, and on 8 May 1994, the committee of the party investigated him and identified other Members of the House of Representative who were allegedly involved with this case. On 11 May 1994, a local court in North California ruled that the case had Prima Facie to believe that Mr. Tanong Siripongpreecha and his wife had been involved with narcotic trafficking in the U.S. The U.S. authority then contacted the Thai counterpart to extradite him and his wife to be on trial at a court in the U.S.

In January 1995, the Criminal Court in Thailand issued the arrest warrant of Mr. Tanong. He, then, surrendered himself and put up a defense.

On 28 December 1994, Mr. Tanong was sentenced to 18 years in prison by a Thai Court. The Ministry of Foreign Affairs then informed the US authority to receive him within 3 months. Later, the U.S. authority brought him to California Court where he was sentenced to 40 months in prison and 5 years' probation without fine. This is an extradition that a Thai national was extradited to stand trial in a court of the requesting state for a criminal offence he had committed within its jurisdiction.

\subsection{Punishment by death}

Death penalty has been abolished in many European states., The maximum punishment is imprisonment for life. Although there is an extradition treaty between these states, 
they shall not extradite any persons to a state where death penalty exists.

There is a case study that the UK refused to execute the extradition request of Thailand since the offence committed by the person sought for extradition have punishment by death as established by Thai law. This case breached the Treaty between the Kingdom of Thailand and the United Kingdom on Extradition A.D. 1991 which does not prescribe that death penalty is the exception of execution of extradition request 7

Negotiation on extradition treaty between Thailand and some European states had to end since there has been abolition of death penalty in those states, while there are a number of offences having punishment by death established by Thai law. To make the extradition between both parties work, the requested state which does not have death penalty in place usually asks

Thailand to ensure that it shall not give punishment by death to a person sought for extradition to Thailand. Later, there was an amendment of the Thai domestic law so as not to be obstacle for the success of extradition. Such amendment appears in Section 29 of the Extradition Act, B.E. 2551 (2008) which provides that "Where Thailand requests extradition on the offence punishable with death according to the Thai law but not up to the punishment of death according to the law of the Requested State and it is of necessity for the Government to give assurances of nonexecution, negotiation for the settlement on giving such assurances shall consequently be carried out. In this respect, if the Court gives a death sentence, the Government shall proceed in accordance with the provision of law for the enforcement of execution according to the judgment by means of life imprisonment in lieu of death. The reduction of such person's punishment shall not be granted in whatever grounds except in the case of the royal pardon." However, although the Thai government undertakes not to give punishment by death to a person sought for extradition, Thai court still has power to sentence such person to death. If this happens, the Department of Correction shall not give death to the person sought by not setting the date of execution so as to keep up with the commitment that the Thai government gave to the requested state.

\section{Contradiction between a treaty and Thai law}

Thailand is a party to the extradition treaties with many states. Obviously, each treaty contains different details from one another. Moreover, some of these treaties might have some provisions which are not consistent with Extradition Act, B.E. 2551 (2008). However, an execution of extradition request shall be carried out in accordance with the treaty since the international law usually prevails if it is contradict to the domestic law.

Extradition Act, B.E. 2551 (2008) reflects this principle as prescribed in Section 4 that "This Act shall be enforced upon the extradition that is not contradictory to or consistent with provisions of the treaty respecting extradition between the Government of Thailand and Foreign Country or international organization."

However, it is important to note that where an extradition treaty and domestic law are not compatible, compliance with the treaty is required if such treaty specifies that the requested state has the obligation to comply with the treaty in the case of contradiction between the treaty and domestic law only. In other words, if the treaty does not require compliance with the obligation in case of such contradiction, the requested state needs not to do so.

\section{Surrendering process}

\subsection{An execution of an extradition request granted by Thailand as a requested state}

When Thailand is requested to execute an extradition request, Thai authority shall consider the request based on a treaty and domestic law. If there is not a treaty, the domestic law shall be solely applied. The Thai authorities dealing with extradition are those under administrative power and judicial power. The authorities under administrative power are the Cabinet, Ministry of Foreign Affairs, Office of the Attorney General, Thai Royal Police, and Department of Correction. The authorities under the administrative power shall consider whether an extradition request shall be executed or not. The court, which is under the judicial power, shall consider the execution request based on legal proceedings. If it complies with conditions set forth under the relevant laws and regulations, the court shall have an order to confine a person sought for to be extradited to the requesting state. As for the execution to be proceeded by authorities under the administrative power, when an extradition request is submitted through diplomatic channel under the supervision of the Ministry of Foreign Affairs, the Ministry shall pass the request to the Office of the Attorney General. After the Attorney General, as the central authority under the Thai Extradition Act, considers the request, if an offence committed by such person is one of those prohibited to execute the extradition such as a political offence, the execution of the request shall not be granted. Then, it shall be sent to the Ministry of Foreign Affairs so that the government can refuse the requesting state. The case shall be ended after the Cabinet approves the refusal of extradition.

If the request meets all requirements set forth in the Extradition Act and a treaty (if any), a public prosecutor shall submit request with the court so that the court can issue the arrest warrant of a person sought for extradition. After such person is arrested, and the public prosecutor shall submit the case the Bangkok Criminal Court where the case shall be considered if the prosecutor's case has sufficient evidence to prove that the person sought is to be extradited according to the conditions set forth in the Extradition Act, B.E. 2551, and the extradition treaty (if any). During this process, the person sought has the right to defend his/her case. If the court, after thorough consideration from the hearings, finds that the case is not prohibited by law or treaty such as it is not a political offence, the case is still in a period of prescription, and it complies with the conditions, the court shall have an order to confine such person to be extradited. It should be noted that it is not authority of the court to order that any persons will be extradited or not, but it is authority under the administrative power. Though the court has an order to confine such person to be extradited, extradition request can be refused if the government considers that it should not be executed. 


\subsection{Extradition request submitted by Thailand as a requesting state}

When an accused commits an offence in Thailand and escapes to a foreign country, it is authority of the Attorney General, the Central Authority, to submit an extradition request through diplomatic channel to the state where such person is residing. In case where there is an extradition treaty between Thailand and the requested state, the Attorney General as the Central Authority can directly submit its request to the Central Authority of such requested state as prescribed in the treaty. However, the address where such person resides must be found prior to submitting the request. It is authority of an investigator to find out where the person sought is located, this includes to contact INTERPOL to find such address. If such address cannot be found, the arrest warrant of such person shall be sent to states all over the world. Sometimes, INTERPOL is requested to contact states so as to find such address and to arrest such person. This is the most effective channel. Especially, if such person was in high position, a leader of state, and a famous person, his movement is known widely. It is easy to find his address and request a state where he is residing to arrest and bring him to extradition process if the case complies with extradition conditions. At present, extradition has economic and political dimensions. Sometimes the suspect uses his economic or political power as a gap in international law to escape from the extradition process. There is a case study to support this argument. It is a case of Mr. Worayuth Yoowittaya9 (BBC-News, 2020).Reuters reported that the Thai Royal Police explained that Thai court had issued the arrest warrant with a charge of causing death by dangerous driving and took cocaine. As a result, member states of INTERPOL shall identify where he is residing "so that he shall be extradited to be on trial." Thai Royal Police presented to Thai BBC on 6 October 2020 that it informed INTERPOL to issue INTERPOL Red Notice10 for Mr. Worayuth on 30 September 2020 so as to request member states to extradite the suspect to face trial at a Thai court. And this request shall be executed or not depends on those member states. The Red Notice issued by INTERPOL does not give authority to police in any states to arrest him. The police must follow domestic laws of their states. There were 3 offences submitted to INTERPOL for Red Notice issuance as follows:

1. causing death by dangerous driving;

2. causing damage to a person by dangerous driving without helping an injured person and not immediately inform official;

3. took narcotics of category 2 (cocaine).

Extradition of Mr. Worayuth shall be requested through diplomatic channel proceeded by the Office of the Attorney General. The request shall be submitted to states where he appears. Currently, there is nothing hinting his address. Thai authority thus cannot submit its request. It is noticeable that although the Red Notice of INTERPOL was sent to all member states, there has not been evidence about him. As being the heir of the brand Red Bull which is one famous brand of beverage, Mr. Worayuth who is wealthy and spends luxury life abroad has not so far been found.

\section{Case study of Mr. Taksin Chinnawat11}

Mr. Taksin Chinnawat is a Former Prime Minister of Thailand who was accused of committing fraud in purchasing land located at Ratchadapisek Road which he gained great benefits whereas his country lost money. Then, he was prosecuted by Public Prosecutor. The Court of First Instance and the Appeal Court ruled, that he was guilty as charged. He lodged an appeal against the Appeal Court's judgement, and he was also granted bail. Then, he escaped to a foreign country. At that time there was coup de' etat, so he requested political asylum in the foreign country where he was issued its passport which he used it when he traveled around the world. In fact, there is a reason to believe that INTERPOL knew when he traveled from a country to a country because he at that time he run international business, trade and investment which could bring benefits to the country he was residing. Until now, he has not yet been extradited to Thailand to serve the punishment according to the judgement of the Supreme Court. The Thai government has tried to diplomatically negotiate with countries where he was hiding to surrender him to Thailand, but those countries did not grant cooperation as expected

\section{Conclusion}

At present, there many factors affecting extradition, such as, diplomatic relation, politics and economy. A person who commits an offence to be extraditable knows the way to escape justice. Moreover, if such person was in high position, the enforcement of extradition treaty, and international cooperation based on reciprocity is ineffective which shall affect enforcement of extradition law. Although process of extradition is executed with respect to the conditions prescribed by law to bring such person to be punished, the final decision belongs to the government of a requested state. A person shall be extradited or not depends on the government consideration of a requested state although the extradition is executed according to international agreement on extradition.

The author would like to reflect that cause of failure in extradition is status of a person sought for extradition. If such person is an influencer who can give effect on economy of a state in which he is residing, it is obvious that the extradition of such person shall not be executed. Extradition is an international issue which must be executed uprightly, fairly, and ethnically, and a state shall perform its duty to cooperate with its contracting party with sincerity so as to suppress crime at both domestic and international levels.

\section{References}

[1] Uthai Athiwet,(2448) Problems and Obstacles to the death penalty and recommendations by The extradition prosecution of the prosecutor, Bangkok, Court of Appeal Publishing (2005), p. 225. 
[2] Pornchai Danwiwat, Somboon Sengiambut, International Criminal Law, Bangkok, Publishers,(2012).pp.76-77.

[3] Court of Appeal , Extradition Act Between Kingdom of Thailand and The United State B.E.2533, Bangkok, Court of Appeal Publishing (2005), p. 297-300.

[4] Neawna-Online, "Urgent, Wattana Assawahem, surfs a book to return to Thailand to the Klong Dan Case", https://www.naewna.com/politic/493022,

Retrieved on 28 October 2020.

[5] Chatpong Wongreanthong, Study the results of Foreign Court judgments on criminal prosecution in Thailand, The Faculty of Law of Thammasat University(2016). pp. 23-25.

[6] Isranews-Online, "Relive the legend of Mr. Thanongsak Siripongpricha former politician who trafficked a U.S. Court to jail to Measure the Thai Leadership norms, https://www.isranews.org/isranewsscoop/80333-isranews-80333.html Retrieved on 30 October, 2020.

[7] Court of Appeal , Announced on Agreement of Extradition between Siam and England, Bangkok, Court of Appeal Publishing (2005), p. 262-263.

[8] Court of Appeal , Extradition Act B.E. 2472, Bangkok, Court of Appeal Publishing (2005), p. 255-258.

[9] BBC-News, Thailand Prepares to request extradition of Red Bull heirs after the Interpol issued a red arrest warrant", , https://www.bbc.com/thai/thailand54424489, Retrieved on 17 October 2020.

[10] A red notice is a request for law enforcement around the world to identify someone who has committed an offense in one country and has fled to another. Therefore requesting that the country in which the operator is found to arrest that person through extradition process The red notice consists of two parts: information about the person who is required to identify, such as name, date of birth, nationality, hair and eye color, photo and fingerprint (if applicable), and information about the crime committed by the person: base on The fault of the person, However, the red notice is issued by Interpol at the request of member states. It must comply with the rules and constitution of Interpol. The red warrant does not hold an international arrest warrant, but is a sign that indicates a person who international wanted persons notice as mentioned above only.

[11] Neawna - Online, "Thaksin Shinawatra hit by Hong Kong media reveals Thai prosecutors submit a letter requesting to be extradited After the news surfaced for the daughter's wedding,'

[12] https://www.naewna.com/politic/402698, Retrieved on 18 October, 2020. 